\title{
ENVIRONMENTAL QUALITY ANALYSIS IN KENDARI BAY IN TERMS OF HEAVY METAL POLLUTANTS : $\mathrm{Pb}, \mathrm{Cu}$ and $\mathrm{Zn}$
}

\author{
Lies Indriyani ${ }^{1}$, Deniyatno ${ }^{2}$, Sahindomi Bana ${ }^{1}$, Ridwan Adi Surya ${ }^{1}$, Junartin Teke \\ ${ }^{1}$ Ilmu Lingkungan, FHIL, Universitas Halu Oleo \\ ${ }^{2}$ Tambang, FTIK, Universitas Halu Oleo \\ Email : lies.said@gmail.com
}

\begin{abstract}
Heavy metal is one of the most pollutant loads that endangers the aquatic environment. Not only damaging the aquatic ecosystem, the presence of heavy metals also endangers the human health. This Research aims to determine the levels of heavy metals, especially $\mathrm{Pb}, \mathrm{Cu}$ and $\mathrm{Zn}$ in water and also the sediments inside Kendari Bay waters. To determine the environmental quality of Kendari Bay waters standards. Sampling was carried out at 10 stations and sample analysis was carried out using the AAS method. Data analysis was performed using descriptive methods. The results showed that heavy metals $\mathrm{Pb}, \mathrm{Cu}$ and $\mathrm{Zn}$ in water ranged $<0.002-0.012 \mathrm{mg} / \mathrm{L}$, for metals ranging from $<0.002-0.003 \mathrm{mg} / \mathrm{L}, \mathrm{Cu}$ metals ranged from $<0.002-0.012 \mathrm{mg} / \mathrm{L}$ and $\mathrm{Zn}$ metals ranged from $<0.002-0.003 \mathrm{mg} / \mathrm{L}$, while heavy metals $\mathrm{Pb}, \mathrm{Cu}$ and $\mathrm{Zn}$ in sediments range $<0.002-0.047 \mathrm{mg} / \mathrm{kg}$, for Pb metals range from 0.052 to $0.047 \mathrm{mg} / \mathrm{kg}$, Cu metals range $<0.002-0.042 \mathrm{mg} / \mathrm{kg}$ and $\mathrm{Zn} \mathrm{metals}$ range from $0,0019-0.011 \mathrm{mg} / \mathrm{kg}$. The heavy metal content of $\mathrm{Pb}, \mathrm{Cu}$, and $\mathrm{Zn}$ in both water and sediment samples has not exceeded the quality standards based on the Decree of the Minister of Environment No.51 of 2004 and USEPA.
\end{abstract}

Keywords: kendari bay, heavy metal, $\mathrm{Pb}, \mathrm{Cu}, \mathrm{Zn}$

\section{A.INTRODUCTION}

Kendari Bay judged by the function are the most developed place in Kendari Town. The bay has some function to develop the Kendari city. The coast itself functioned as a gate of vehicle and goods transportation. People used the gate as a goods transportation whenever they want to get in or out of a city. The beach fucntioned as a place of settlement, hospitality, industrial, business, ponds, recreational facilities and sports place. The increased activity of the bay has some negative effect such as the rise of pollutant surrounding the area. In addition, the habbit of Kendari Bay's people such as throwing garbage into the body of water are also become one of the reason why the pollutant is rising. This is such a big problem to the bay and the city itself because Kendari Bay is also the estuary of all flowing water in Kendari City.

The rush of pollutants in Kendari Bay greatly affects the quality of the aquatic environment. The quality of Kendari Bay's waters becomes very important because it is related to the marine biota that lives in it. The coastal 
area are the place for those marine biota and the place that has the best nutrient for the marine biota especially the fish. The nutrient will rush from the river and flows directly to the sea. Another beneficial element apart from nutrinet and not-so beneficial element or even a bad element which could cause some major problem surrounding the coastal area will also be rush to the sea if the element get thrown in to the rivers flow. Some of the research result shows that sediments act as reservoir for all the contaminants and dead organic matter descending from the ecosystem above. The relatively high concentrations of heavy metals during winter coincide principally with decreasing rate of organic matter decomposition, due to low water temperature (Bazzi, A.O, 2014). Essentialy metal interaction in the environment affected by the heavy metal phase with it's surrounding area. Metal in a shape of sediment has a stronger bond than when the metal is in particulates or dissolved forms (Zhang et all, 2018).

The journey of metal ions in the water travels into the sediment mainly processes through the water-sediment partitioning, the transfer journey of metals from the dissolved form in water into the sediment through the process of adsorption phenomenon. This is the reason why heavy metals in the river ecosystem accumulate in sediments. Heavy metals form in high amounts from the results of this accumulation process has the potential as toxic pollutants. (Schnoor, 1996).

Lead $(\mathrm{Pb})$, Copper $(\mathrm{Cu})$ and Zinc (Zn) are heavy metals that are mostly found as pollutants in water areas. Polluted waters by this heavy metals element will result in contamination of the marine biota and also will result to them becomes unsafe for the people who consume them. The presence of $\mathrm{Pb}, \mathrm{Cu}$ and $\mathrm{Zn}$ in the body will cause bad effects on people's health, such as central nervous system disorders, kidney and liver damage, lung cancer and even death (Darmono, 1995). Considering the negative impacts caused by this heavy metals elements, it becomes very important things to conduct research on the Environmental Quality Analysis of water judged by the contents of Heavy Metal Levels of $\mathrm{Pb}, \mathrm{Cu}$ and $\mathrm{Zn}$ in Kendari Bay Waters.

\section{B. MATERIALS AND METHODS}

This research was conducted from August to November 2019. Sampling was taken out around the waters of Kendari Bay. Sample preparation and analysis was taken out at the Southeast Sulawesi Provincial Environmental Agency Laboratory. 
The population in this Research is the water along the Kendari Bay. The research sample are focused on locations that sea water and fresh water meet (waterways that carry garbage and oil spills) as well as waste disposal points around the Kendari Bay area.

The sampling content in Kendari Bay was taken out using Core sampler Water for water samples and Core Sampler Sediment for sediment samples. Water and sediment samples are put into sample containers that have been labeled according to the station. The sampling locations chosen were 10 stations with the following location details.

1. Stasiun 1 : Nusantara Harbor

2. Stasiun 2: Auction Market

3. Stasiun 3 : Kendari Water Sport

4. Stasiun 4 : Tracking Mangrove Lahundape

5. Stasiun 5 : Triping 1 Bridge (Next to Masjid Al-Alam)

6. Stasiun 6: Triping 2 Bridge (Next to RM. Kampung Bakau)
7. Stasiun 7 : Next to Resort

8. Stasiun 8: Samudera Harbor

9. Stasiun 9: Behind Lapulu Market

10. Stasiun 10 : Kuning Bungkutoko Bridge

The direct measured parameters in the field are water $\mathrm{pH}$, sediment $\mathrm{pH}$, Water temperature, Sediment temperature, DO and Salinity. While measurements of heavy metal content of $\mathrm{Pb}, \mathrm{Cu}$ and $\mathrm{Zn}$ are carried out in the laboratory using an AAS (Atomic Absorption Spectrophotometer) instrument.

C. RESULTS AND DISCUSSION

1. $\mathrm{Pb}, \mathrm{Cu}$ and $\mathrm{Zn}$ Heavy Metal Content in Water and Sediment

\section{Samples}

Tabel 1. Heavy metal concentrations of $\mathrm{Pb}, \mathrm{Cu}$ and $\mathrm{Zn}$ in water and sediment samples at 10 stations 


\begin{tabular}{ccccccc} 
Stations & \multicolumn{2}{c}{ Pb Metal } & \multicolumn{2}{c}{ Cu Metal } & \multicolumn{2}{c}{ Zn Metal } \\
\cline { 2 - 7 } & $\begin{array}{c}\text { Water } \\
(\mathrm{mg} / \mathrm{l})\end{array}$ & $\begin{array}{c}\text { Sediment } \\
(\mathrm{mg} / \mathrm{kg})\end{array}$ & $\begin{array}{c}\text { Water } \\
(\mathrm{mg} / \mathrm{l})\end{array}$ & $\begin{array}{c}\text { Sediment } \\
(\mathrm{mg} / \mathrm{kg})\end{array}$ & $\begin{array}{c}\text { Water } \\
(\mathrm{mg} / \mathrm{l})\end{array}$ & $\begin{array}{c}\text { Sediment } \\
(\mathrm{mg} / \mathrm{kg})\end{array}$ \\
$\mathbf{1}$ & $<0,002$ & 0,035 & 0,002 & $<0,002$ & $<0,002$ & 0,0035 \\
$\mathbf{2}$ & 0,003 & 0,017 & 0,012 & 0,0012 & 0,003 & 0,011 \\
$\mathbf{3}$ & $<0,002$ & 0,047 & $<0,002$ & $<0,002$ & $<0,002$ & 0,007 \\
$\mathbf{4}$ & $<0,002$ & 0,012 & $<0,002$ & 0,002 & $<0,002$ & 0,002 \\
$\mathbf{5}$ & $<0,002$ & 0,02 & 0,002 & 0,002 & 0,002 & 0,0026 \\
$\mathbf{6}$ & 0,002 & 0,017 & 0,002 & 0,002 & 0,002 & 0,0047 \\
$\mathbf{7}$ & $<0,002$ & 0,014 & 0,0022 & 0,0042 & $<0,002$ & 0,004 \\
$\mathbf{8}$ & $<0,002$ & 0,012 & 0,002 & 0,0019 & $<0,002$ & 0,019 \\
$\mathbf{9}$ & 0,003 & 0,02 & 0,0031 & $<0,002$ & 0,003 & 0,0062 \\
$\mathbf{1 0}$ & $<0,002$ & 0,0052 & $<0,002$ & $<0,002$ & $<0,002$ & 0,0052 \\
\hline
\end{tabular}

Source: Southeast Sulawesi Province BLH Laboratory, 2019

The results shows that the contents of $\mathrm{Pb}$ heavy metal concentrations in water samples in the waters of Kendari Bay show almost constant values at all stations. The results of the analysis of $\mathrm{Pb}$ concentrations in water samples tend to be constant at values $<0.002$ mg / 1. Based on the Decree of the Minister of Environment No.51 of 2004, the safe threshold value of $\mathrm{Pb}$ for marine biota is $0.008 \mathrm{mg} / \mathrm{l}$. Thus based on the KMNLH stipulation, the $\mathrm{Pb}$ content in this Research is relatively good and will not be harmful to the marine biota and aquatic organisms. considering the $\mathrm{Pb}$ level of 0.1-0.2 mg / 1 is able to cause some poisoning in certain types of fish (Thamzil et al,
1998) and at a rate of $188 \mathrm{mg} / 1 \mathrm{can}$ kill some marine biota (Palar, 1994).

$\mathrm{Pb}$ Metal are very toxic, and also can cause major bioaccumulative properties inside the body of aquatic organisms, and will continue to accumulate until the organism is no longer able to tolerate the heavy metal content of $\mathrm{Pb}$ Metal in its body. Murphy (1979) reported that aquatic biota such as crustaceans would experience death after 245 hours, if the body of water contained $\mathrm{Pb}$ Metal of 2.75-49 mg / 1 . Other aquatic biota, from the insect group, will experience death in a longer time span that is between 168-336 hours, if the waters contain $\mathrm{Pb}$ Metals of 3.5-64 mg / 1. 
$\mathrm{Pb}$ metal is often found and used in various human activities. $\mathrm{Pb}$ metal contamination usually originates from industrial wastes and is also discharged from motor vehicle, fuel and plastic waste. $\mathrm{Pb}$ metal which originates from waste byproducts from combustion of motorized vehicle fuel can then enter the water body around the source of pollution. In waters environment, the source of $\mathrm{Pb}$ metal can also also comes from limestone.

The results of $\mathrm{Cu}$ heavy metal concentrations in water samples in Kendari Bay waters show almost constant values at all stations which in value of $<0.002 \mathrm{mg} / 1$, except at station 2. Based on KMNLH No.51 of 2004, the threshold value of $\mathrm{Cu}$ levels that are safe for biota the sea is 0.008 $\mathrm{mg} / \mathrm{l}$. From 10 stations, there is 1 station which has $\mathrm{Cu}$ levels exceeding the quality standard which reaches $0.012 \mathrm{mg} / 1$, it is station 2 .

Station 2 which is a place for fish auction is a location which are very prone to pollution including heavy metal pollution. The market location which is very close to the coastal area makes the water condition around the market is very dirty. The number of solid and liquid market waste discharges, community activities in settlements, fishing port activities, as well as its location close to gas stations makes the heavy metal of $\mathrm{Cu}$ pollution in these locations are almost unavoidable.

Connel dan Miller (1995) states that $\mathrm{Cu}$ are essential metal which if in low concentrations can stimulate the growth of organisms but while in high concentrations can be a barrier. Palar (1994) states that marines biota are very sensitive to excess $\mathrm{Cu}$ inside the waters as a place of life. The concentration of dissolved $\mathrm{Cu}$ which reaches $0.01 \mathrm{mg} / 1$ will cause death for phytoplankton. And within 96 hours, the marine biota belonging to Mollusca will experience death if the $\mathrm{Cu}$ dissolved in the water body is in the range of $0.16-0.5 \mathrm{mg} / 1$.

The results of the concentration of $\mathrm{Zn}$ heavy metals in water samples inside the Kendari's water bay shows a value that is also almost constant at all stations. The results of the analysis of $\mathrm{Zn}$ concentrations in water samples tend to be constant at values $<0.002$ mg / 1. Based on KMNLH No.51 of 2004, the safe threshold value of $\mathrm{Zn}$ for marine biota is $0.05 \mathrm{mg} / \mathrm{L}$. Thus based on the KMNLH stipulation, Zn levels in this Research are still good and not yet harmful to the life of marine and aquatic organisms. 
$\mathrm{Zn}$ metal is widely used in battery materials. Zinc in the form of oxide is used for the cosmetics industry (preventing skin from drying out and not getting sunburned), plastics, soap rubbers, white pigments in paints and inks $(\mathrm{ZnO})$, zinc in sulfide form is used as phosphorous pigments as well as for the tube television industry and fluorescent lights. Zinc in the form of chloride is used as deodorant and wood preservation, zinc sulfate for mordan (staining), styptic (to prevent bleeding) as a supply of zinc in animal food and fertilizer, as a paint release especially in the auto car industry, and as a metal floor wall material for kitchen insecticide ingredients (Maslukah, 2006).

Consumption of zinc in large quantities or more can cause vomiting, diarrhea, fever, fatigue, anemia and reproductive disorders (Deswati et al, 2013). Some fish can accumulate zinc in their bodies, when the fish live in waters that have been contaminated with zincZinc is not always toxic, because a certain amount of zinc is needed by the body, zinc is also found in iris, retina, liver, pancreas, kidney, skin, muscles, testes and hair, so zinc deficiency affects these tissues (Begum dkk, 2009).
Estuary is a transitional area between land and sea that is mostly affected by pollution. This is because the materials are contaminated both from rivers as a result of human activities on land such as industry, mining, household waste, garbage disposal and so on. While from the sea, for example, activities at the port and oil spills from the ship will accumulate in estuaries. As a result, estuaries that previously had a very important function to support a variety of life both organisms (as a place of spawning, shelter and foraging) as well as supporting other ecosystems can no longer play this important role.

Estuary is characterized by areas that have high turbidity caused by river water input and sediment resuspension. In estuarine waters where freshwater mass encounters (low salinity and have weak ionic strength) with sea water (high salinity and have higher ionic strength) result in the destabilization of suspended solids particles, forming aggregation followed by precipitation due to the force gravity (Chester, 1990). The destabilization process causes the concentration of dissolved metals in the estuary to experience a reduction (removal) and increase its concentration in sediments (Sanusi, 2006). 
In general, differences in metal concentrations at each station are caused by various physical, biological and chemical processes in the waters. Physical processes in the waters cause the process of stirring and sedimentation. The physics process is influenced by environmental conditions such as currents that affect the rate of precipitation.

Basically the concentration of seawater tends to be temporary and is influenced by tidal currents and other movements that rapidly dilute the concentration of heavy metals (Chakraborty and Owens, 2014). But on the other hand, currents cause friction between the surface of the sediment and the mass of water. This will result in particle releases in the sediment into the water column, thus potentially also causing the increase of the concentration of heavy metals in suspended particles. Biological processes in the waters will affect the activity of marine biota in the water and microbial columns in the sediment which will result in increased accumulation of heavy metals.

The results showed that heavy metals $\mathrm{Pb}, \mathrm{Cu}$ and $\mathrm{Zn}$ in sediments ranged $<0.002-0.047 \mathrm{mg} / \mathrm{kg}$, for $\mathrm{Pb}$ metals ranged from 0.052 to $0.047 \mathrm{mg} /$ $\mathrm{kg}, \mathrm{Cu}$ metals ranged from $<0.002$ -
$0.042 \mathrm{mg} / \mathrm{kg}$ and $\mathrm{Zn}$ metals ranged from $0.0019-0.011 \mathrm{mg} / \mathrm{kg}$.

On the seabed, sedimentary fractions are dominated by coarse sand. Ocean areas have currents that are large enough and more dynamic so that only large enough material can be deposited. Strong currents also allow resuspension and desolation of heavy metals from sediments into the water column. The size of sediment grains that vary at each sampling station is estimated to come from material in the surrounding environment that affects the formation of sediment. Seawater variability such as waves and currents is also thought to be one of the factors causing differences in texture composition at the sampling station.

From the results of the Research note that the $\mathrm{Pb}$ metal is a heavy metal which has the highest concentration compared to $\mathrm{Cu}$ and $\mathrm{Zn}$ metals. This shows that community activities around Kendari Bay release a lot of $\mathrm{Pb}$ metal in the waters. The increasing number of motor vehicle users in Kendari City will certainly increase the concentration of $\mathrm{Pb}$ discharges in the environment. In addition, the habits of the people of Kendari City that dispose of domestic waste in the form of batteries and used cans that contain $\mathrm{Pb}$ metal to water bodies, also cause high 
$\mathrm{Pb}$ concentrations in the waters. Even so the levels of heavy metals $\mathrm{Pb}, \mathrm{Cu}$ and $\mathrm{Zn}$ in sediments have not exceeded the quality standards based on the United States Environmental
Protection Agency (USEPA). The quality standard for each of the heavy metals $\mathrm{Pb}, \mathrm{Cu}$ and $\mathrm{Zn}$ in sediments based on USEPA is shown in the following Table 2.

Tabel 2. The quality standard for heavy metals in sediments is based on USEPA

\begin{tabular}{cccccc}
\hline No & $\begin{array}{c}\text { Metals } \\
(\mathrm{mg} / \mathrm{kg})\end{array}$ & $\begin{array}{c}\text { Does not cause } \\
\text { pollution } \\
(\mathrm{mg} / \mathrm{kg})\end{array}$ & $\begin{array}{c}\text { Medium cause } \\
\text { pollution } \\
(\mathrm{mg} / \mathrm{kg})\end{array}$ & $\begin{array}{c}\text { Hugh cause } \\
\text { pollution } \\
(\mathrm{mg} / \mathrm{kg})\end{array}$ & $\begin{array}{c}\text { Research Result } \\
(\mathrm{mg} / \mathrm{kg})\end{array}$ \\
\hline $\mathbf{1}$ & $\mathrm{Pb}$ & $<40$ & $40-60$ & $>60$ & $0,052-0,047$ \\
$\mathbf{2}$ & $\mathrm{Cu}$ & $<25$ & $25-50$ & $>50$ & $<0,002-0,042$ \\
$\mathbf{3}$ & $\mathrm{Zn}$ & $<90$ & $90-200$ & $>200$ & $0,0019-0,011$ \\
\hline
\end{tabular}

Sumber : USEPA, 1977

\section{Physical and Chemical Parameters}

\section{a. Temperature}

The temperature of a body of water is influenced by the season, latitude, altitude from sea level, time of day, water circulation, cloud cover, and the flow and depth of the water body. Temperature is one of the important factors in regulating life processes and the spread of organisms, especially in the aquatic environment. The increase in temperature results in a decrease in the solubility of gases in water such as $\mathrm{O} 2, \mathrm{CO} 2, \mathrm{~N} 2, \mathrm{CH} 4$ and others. Besides the increase in temperature also causes an increase in the speed of metabolism and respiration of organisms which subsequently results in an increase in oxygen consumption. At an increase in temperature of $10 \mathrm{oC}$ the water causes an increase in oxygen consumption by aquatic organisms about 2-3 times. However, this increase in temperature is accompanied by a decrease in dissolved oxygen levels so that the presence of oxygen is often unable to meet the oxygen demand for aquatic organisms to carry out metabolic and respiratory processes. Hutagalung and Riyono (1997) say that rising temperatures will not only increase the metabolism of aquatic biota, but also can increase the toxicity of heavy metals in the waters. The higher the temperature, the greater the solubility of heavy metals in the water. 
With higher temperatures to a certain extent the process of photosynthesis will be more passive because temperature has an important influence on the life processes of fish and other aquatic animals such as lust, respiration, reproduction and growth. The relatively high rise in water temperature is often marked by the appearance of fish and other aquatic animals to the surface of the water in search of oxygen. If these temperatures are not returning to normal temperatures, it can cause the death of fish and other aquatic animals. Water temperature especially in the surface layer is determined by solar heating whose intensity changes with the time, therefore sea water temperature will be in line with changes in the intensity of solar radiation.

Tabel 3. Physical and chemical parameters in water and sediment samples at 10 stations

\begin{tabular}{cccccccc}
\hline Station & $\begin{array}{c}\text { Water } \\
\text { Temperature } \\
\left({ }^{\mathbf{O}} \mathbf{C}\right)\end{array}$ & $\begin{array}{c}\text { Water } \\
\mathbf{p H}\end{array}$ & $\begin{array}{c}\text { DO } \\
(\mathbf{m g} / \mathbf{L})\end{array}$ & $\begin{array}{c}\text { Salinity } \\
(\boldsymbol{\%})\end{array}$ & $\begin{array}{c}\text { TSS } \\
(\mathbf{m g} / \mathbf{L})\end{array}$ & $\begin{array}{c}\mathbf{p H} \\
\text { Sediment }\end{array}$ & $\begin{array}{c}\text { Sediment } \\
\text { Temperature } \\
\left({ }^{\mathbf{}} \mathbf{C}\right)\end{array}$ \\
\hline $\mathbf{1}$ & 30 & 7,8 & 6 & 10 & 28 & 7,4 & 14,4 \\
$\mathbf{2}$ & 33 & 7,7 & 6,8 & 4 & 15 & 7,2 & 15,8 \\
$\mathbf{3}$ & 32 & 7,8 & 7 & 8 & 26 & 6,6 & 17,7 \\
$\mathbf{4}$ & 34 & 7,5 & 6,2 & 5 & 10,2 & 7,4 & 17,5 \\
$\mathbf{5}$ & 33 & 7,8 & 6,8 & 14 & 10 & 6,8 & 17 \\
$\mathbf{6}$ & 30 & 7,5 & 7,4 & 11 & 19 & 6,3 & 19,3 \\
$\mathbf{7}$ & 32 & 7,9 & 7,2 & 5 & 28 & 6,9 & 20 \\
$\mathbf{8}$ & 31 & 7,9 & 7,6 & 13 & 15 & 7,6 & 19,3 \\
$\mathbf{9}$ & 31 & 7,8 & 6 & 11 & 12 & 7,3 & 18,6 \\
$\mathbf{1 0}$ & 31 & 8 & 7,6 & 6 & 22 & 6,4 & 16,7 \\
Rerata & $\mathbf{3 1 , 7}$ & $\mathbf{7 , 7 7}$ & $\mathbf{6 , 8 6}$ & $\mathbf{8 , 7}$ & $\mathbf{1 8 , 5 2}$ & $\mathbf{6 , 9 9}$ & $\mathbf{1 7 , 6 3}$ \\
\hline
\end{tabular}

Source: Southeast Sulawesi Province BLH Laboratory, 2019

From Table 3 it shows that the temperature inside the waters in Kendari Bay ranges from $30-34 \mathrm{oC}$ with an average of $31.7 \mathrm{oC}$, where the lowest measured temperature at stations 1 and 6 is $30 \circ \mathrm{C}$ and the highest measured temperature at station 4 is $34 \mathrm{oC}$. This temperature variation occurs because the temperature measurements has been taken out during the daytime so there is the effect of solar radiation. Temperature distribution in estuarine waters is mainly influenced by the duration of sun exposure. In addition, variations in temperature are also caused by conditions around the location of the 
sampling point. The location of sampling points that are covered by mangrove buildings and vegetation tends to have lower temperatures than the location of sampling points with open areas. The building of mangrove vegetation prevents sun exposure to the surface of the sea so that the water temperature tends to be lower.

The measured temperature range in Kendari Bay is still above the water temperature in general sea water, where the normal sea surface temperature values range from 2030oC (Nybakken, 1988). However, this situation is still quite reasonable for tropical waters. Ilahude dan Liasaputra (1980) states that tropical water temperature variations are considered reasonable if the value ranges between 25.6-32.3oC. According to the Ministry of Environment's report (1985), temperatures that are commonly found in Indonesian marine waters range between 27-32oC. This temperature is also still suitable for marine life (fish and so on). Temperature for marine biota is in the range of $28-32 \mathrm{oC}$ and is allowed to occur at changes up to $<2 \mathrm{oC}$ from natural temperatures (KLH, 2004).
The results of this temperature measurement are not different from the results of the Research (Winnarsih dkk, 2016) states that the temperature in the waters of Kendari Bay ranges from 28-31oC. The distribution of seawater temperature in waters is influenced by many factors including solar radiation, geographical location of the waters, circulation of currents, depth of the sea, wind and seasons (Sidjabat, 1976).

\section{b. pH}

Brackish water acidity is relatively stable between $7-8.5$ and changes (fluctuations) in $\mathrm{pH}$ are also relatively small (Odum, 1971). This indicates that the waters are buffers. Marine and aquatic organisms have different abilities in tolerating aquatic pH. Death is mostly caused by a low $\mathrm{pH}$ rather than a high $\mathrm{pH}$. The tolerance limit of marine and aquatic organisms to $\mathrm{pH}$ varies, and it is also influenced by many factors including temperature, dissolved oxygen, alkalinity, the presence of various anions and cations, types and stages of organisms (Odum, 1971).

Based on the measurement results, the $\mathrm{pH}$ value in the waters of 
Kendari Bay is in the range of 7.57.9 with a mean of 7.77 , the lowest measured $\mathrm{pH}$ value at stations 4 and 6 ie 7.5 and the highest measured at stations 7 and 8 namely 7,9 . The range of $\mathrm{pH}$ values is still within safe limits for the $\mathrm{pH}$ of a waters. Generally the $\mathrm{pH}$ of sea water is relatively stable with a range between 7.5-8.4. Pescod in Susan (2005) provides an ideal $\mathrm{pH}$ range for marine life with values ranging from 6.5 to 8.5. Whereas KLH (2004) determined the $\mathrm{pH}$ value for marine biota ranged from 7-8.5. The degree of acidity is affected by the buffer capacity, which is the presence of carbonate salts and binakarbonate they contain (Nybakken, 1992).

The $\mathrm{pH}$ value of waters has a close relationship with the solubility of heavy metals. At the natural $\mathrm{pH}$ of the sea, heavy metals are difficult to decompose in the form of particles or suspended solids. At low $\mathrm{pH}$, heavy metal free ions are released into the water column. Besides this, $\mathrm{pH}$ also influences the toxicity of a chemical compound. In general heavy metals will increase its toxicity at low $\mathrm{pH}$, whereas at high $\mathrm{pH}$ heavy metals will experience precipitation (Sarjono,
2009). Connel dan Miller (1995) states that an increase in $\mathrm{pH}$ in the waters will be followed by a decrease in the solubility of heavy metals, so heavy metals tend to precipitate.

The results of this $\mathrm{pH}$ measurement are not much different from the results of research by Armid (2015) which states that the $\mathrm{pH}$ in the waters of Kendari Bay ranges from 7.23 to 8.01 .

\section{c. Salinity}

Salinity is a chemical parameter that describes the total solids in water, and carbonates (CO32-) which have been converted into oxides, bromides and iodides and replaced by chlorides and all organic matter which has been completely oxidized (Sanusi, 2006). Salinity has a different value in each location. This is influenced by various factors such as water circulation, evaporation, rainfall and river flow (Nontji, 1987). In general, off-shore waters have a salinity of $3.5 \%$.

The salinity value of waters in Kendari Bay at 10 stations ranged between $4-14 \%$ with an average of $6.99 \%$. The highest measured salinity at station 5 is $14 \%$ and the lowest measured salinity at station 2 
is $4 \%$. The salinity value is certainly quite high when compared to the salinity value of Indonesian seas in general, which is around $2.8-3.3 \%$.

The mangrove and estuary areas in Kendari Bay are incorporated in estuary habitat, which is a semi-enclosed river estuary that is freely related to the sea, so that high salinity sea water can be mixed with fresh water. This area has a complex salinity structure, because in addition to being a meeting between fresh water that is relatively lighter in salt content and heavier sea water, stirring water is also very crucial. The difference in salinity of sea water with river water that meets in the estuary causes the two to mix to form brackish water. Because the salt content of sea water is greater, then sea water tends to move at the bottom of the water while fresh water at the surface. On land, the salinity of the estuary (mangrove area) tends to be lower (Armid, 2015). Salinity will vary vertically and horizontally depending on freshwater, rainwater, and evaporation inputs.

The increase in salinity value has a negative effect on heavy metal content, the higher the salinity, the lower the heavy metal content. The increase in salinity causes the $\mathrm{pH}$ to rise, the solubility of metals in the water decreases due to the stability changing from the form of carbonate to hydroxide which forms bonds with particles in water bodies, thus settling to form sludge. Heavy metal content in sludge in sediments has a positive correlation, where the more sludge content in the sediment, the higher levels of heavy metals contained in the sediment and resulting in surface waters have lower metal content.

\section{d. DO (Dissolved Oxygen)}

The measurement results of dissolved oxygen levels in the waters of Kendari Bay obtained values ranging from 6-7.6 mg / L with an average of $6.86 \mathrm{mg} / \mathrm{L}$, with the highest DO measured at stations 8 and 10 ie $7.6 \mathrm{mg} / \mathrm{L}$ and the lowest measured at stations 1 and 9 which is $6 \mathrm{mg} / \mathrm{L}$. Dissolved oxygen conditions are affected, among others, by temperature, salinity, water mass movement, pressure, atmosphere, phytoplankton concentration and the surrounding oxygen saturation level and the stirring of water mass by the wind. Decreased levels of dissolved 
oxygen include, among others, the release of oxygen into the air, the flow of ground water into the waters, the presence of iron, the reduction, which is caused by the pressure of other gases in the water, the respiration of biota and the decomposition of organic matter (Nybakken, 1988). Besides that, plankton also has a role on dissolved oxygen such as decreasing dissolved oxygen levels at night. because dissolved oxygen is used for respiration and increased dissolved oxygen due to photosynthesis during the day. Decreased levels of dissolved oxygen in moderate amounts will reduce the physiological activities of living things in water including a decrease in appetite, growth and swimming speed of fish. Dissolved oxygen levels in these waters decrease with increasing depth.

DO levels in waters that have not been polluted have a DO range> $6.5 \mathrm{mg} / \mathrm{L}$, while waters that have been lightly polluted have a DO range of $4.5-6.5 \mathrm{mg} / \mathrm{L}$, moderate polluted waters have a DO range of $2.0-4.4 \mathrm{mg} / 1$, heavily polluted waters have a DO range of $<2.0 \mathrm{mg}$ / L. Based on this data can be grouped the level of pollution that occurs in the waters of Kendari Bay. Stations 1, 4 and 6 are included in lightly polluted waters with DO values of $6,6.2$ and 6 respectively. Port of the archipelago, Tracking Mangrove Lahundape, Rear Lapulu Market is an area prone to pollution. Port activities, market waste discharges, household waste discharges which all lead to Kendari Bay will certainly reduce the environmental quality of Kendari Bay waters.

The availability of oxygen in waters certainly cannot be separated from the presence of mangrove areas as oxygen production around the waters of Kendari Bay. Besides the conversion of the function at the mangrove area into a recreational facility actually makes the function of the mangrove area are not going well. Kendari City residents who visit the mangrove tourism area tend to dispose of their garbage in the waters of Kendari Bay so that the sea level in the tourist area is covered by both organic and nonorganic waste. The presence of waste in the waters will certainly greatly affect the level of dissolved oxygen in it. The higher the amount of waste, the dissolved oxygen levels will decrease too, this is 
because to decompose these wastes microorganisms require a lot of oxygen. Low dissolved oxygen will cause a decrease in fish survival, affect the speed of eating fish and reduce metabolic processes of fish even at very low concentration levels can kill fish and other biota.

\section{e. TSS (Total Suspended Solid)}

The measurement results of TSS levels in the waters of Kendari Bay obtained values ranging from 10-28 $\mathrm{mg} / \mathrm{L}$ with an average of $18.52 \mathrm{mg} / \mathrm{L}$. Total suspended solid is solids element that cause turbidity of water, are insoluble and cannot directly settle, consisting of particles smaller in size and weight than sediments such as mud, clay, metal oxides, sulfides, algae, bacteria and fungi. TSS is directly proportional to turbidity, so if the TSS value is high then the turbidity value will also be high. Another cause is the high TSS flow velocity, the higher the flow velocity, the higher the TSS.

The TSS value obtained in this research is still below the quality standard set by the Decree of the Minister of Environment No.51 of 2004 which is $80 \mathrm{mg} / \mathrm{L}$ for marine tourism and temporary mangroves for $20 \mathrm{mg} / \mathrm{L}$ for seagrasses and corals. The highest TSS level measured at stations 1 and 7 is 28 $\mathrm{mg} / \mathrm{L}$ and the lowest measured at station 5 is $10 \mathrm{mg} / \mathrm{L}$. High TSS levels at stations 1 and 7 show that port activities and land use change activities in which there are dredging and reclamation activities around the Kendari Bay area contribute to solids into the waters.

Suspended solids element are the place where heterogeneous chemical reactions take place and function as the earliest precipitating agents and can inhibit the ability to produce organic matter in a waters (Tarigan and Edward, 2003). High TSS can cause a decrease in the photosynthetic activity of marine plants both micro and macro so that the oxygen released by plants becomes reduced and causes fish to die (Helfinalis et al, 2012). So if the TSS concentration in the river body continues to increase and flow into the high seas for a long period of time it can reduce the quality of the waters.

\section{CONCLUSIONS}

Based on the data obtained it can be concluded that the levels of heavy metals $\mathrm{Pb}, \mathrm{Cu}$ and $\mathrm{Zn}$ in the water environment 
of Kendari Bay are still safe for marine biota based on quality standards set by the State Minister for Environment No.51 of 2004 and the United States Environmental Protection Agency (USEPA). The recommendation in this Research are as follows: (a) Analysis of heavy metal content in the waters of Kendari Bay needs to be done continuously to determine the dynamics of heavy metals from time to time. (b) There is a need for supervision of households and industries that dispose their waste in water bodies, in order to control the concentration of pollutants in this case heavy metals. (c) Mangrove areas that are being used as tourist attractions need to be preserved, so the function of mangrove forests as bioremediation can run optimally.

\section{E. REFERENCES}

Armid., 2015, Distribusi Spasial Logam Berat $\mathrm{Pb}$ Pada Perairan Teluk Kendari Sulawesi Tenggara, Biowallacea, Vol. 2 (2) : Hal 220228.

Begum, A., Harikrishna dan Khan, I. 2009. Analysis of Heavy Metal in Water, Sediments and Fish Samples of Madivala Lakes of Bangalore, Kartanaka. International Journal of ChemTech Research CODEN (USA): IJCRGG, 1 (1), 39-47.

Connel dan Miller, 1995, Kimia dan Etoksikologi Pencemaran, diterjemahkan oleh Koestoer, S., Hal. 419, Indonesia University Press, Jakarta.
Darmono, 1995, Logam Dalam Sistem Biologi Makhluk Hidup, UI Press, Jakarta.

Deswati, Suyani, H., dan Chairini, N., 2013. Studi Optimal Penentuan Seng secara Voltametri Stripping Adsorpsif (adSV). Jurnal Kimia Unand, 2 (1), 98-106.

Helfinalis, Sultan dan Rubiman., 2012, Padatan Tersuspensi Total di Perairan Selat Flores Boleng Alor dan Selatan Pulau Adanara Lembata Pantar. Vol.17 (3) 148-153.

Hutagalung. H.P., 1991, Pencemaran Laut Oleh Logam Berat. Puslitbang Oseanologi, Status Pencemaran Laut di Indonesia dan Teknik Pemantauannya, LIPI, Jakarta.

Kementrian Lingkungan Hidup, 2004, Peraturan Pemerintah Republik Indonesia Nomor 82 Tahun 2004 Tentang Pengelolaan Kualitas Air dan Pengendaian Pencemaran Air. Kementrian Lingkungan Hidup. Jakarta.

Keputusan Menteri Lingkungan Hidup Nomor 51 Tahun 2004 Tentang Baku Mutu Air Laut.

Nontji, A., 1987, Laut Nusantara, Djambatan, Jakarta.

Nybakken, J. W., 1988, Biologi Laut Suatu Pendekatan Biologis, PT Gramedia. Jakarta.

Nybakken, J. W., 1992. Biologi Laut Suatu Pendekatan Ekologis. PT. Gramedia. Jakarta.

Maslukah, L., 2006, Konsentrasi Logam Berat $\mathrm{Pb}, \mathrm{Cd}, \mathrm{Cu}, \mathrm{Zn}$ dan Pola Sebarannya di Muara Banjir Kanal Barat, Semarang (Tesis), Sekolah Pasca Sarjana Program Studi Ilmu Kelautan, Institut Pertanian Bogor, Bogor.

Murphy, M., A Manual for Toxicity Tests with Fresh Water Macrointervebrates and a Review of 
the Effects of Specific Toxicants. University of Wales Institute of Science and Technology Publication, 1979, 134.

Odum, E.P., 1971, Fundamental of Ecology, W.B. Saunders Company, London-Toronto.

Palar, H., 1994, Pencemaran dan Toksikologi Logam Berat, Penerbit Rineka Cipta, Jakarta.

Sanusi, H. S., 2006, Kimia Laut Proses Fisik Kimia dan Interaksinya dengan Lingkungan, Bogor : Departemen Ilmu dan Teknologi Kelautan Fakultas Perikanan dan Ilmu Kelautan Institut Pertanian Bogor. Bogor.
Schnoor, J.L., 1996, Environmental Modeling: Fate and Transport of Pollutants in Water, Air and Soil, John Wiley \& Sons Inc.

Susana, T., 2005, Kualitas Zat Hara, Perairan Teluk Lada, Banten, Oseoanalogi, dan Limnologi di Indonesia. 59-67.

Tarigan, M.S dan Edward., 2003, Kandungan Total Zat Padat Tersuspensi (Total Suspended Solid) di Perairan Raha, Makara, Sulawesi Tenggara.

U.S Environmental Protection Agency (U.S. EPA), Guidance for the Pollutional Classification of Great Lakes Harbor Sediments, Regional V, Chicago, Illnois, 1977. 